Pavlishyna Nina,

$\mathrm{PhD}$ in Economics, National University «Zaporizka politekhnika»

Zaporizhzhya, Ukraine

ORCID: 0000-0001-7715-9202

Reseacher ID: G-2945-2019

\title{
DEVELOPMENT OF THE CRIMEA BUSINESS IN THE CONDITIONS OF GEOPOLITICAL UNCERTAINTY
}

The article deals with the business environment of Crimea in terms of global economic and geographical transformations. The economic indicators are analyzed, the factors that negatively influence the economic situation of the republic are noted. The directions of normalization of the geo-economic situation of Crimea, which is in direct dependence on the geopolitical situation on the peninsula, to increase the efficiency of the use of own resources for ensuring prosperity, are outlined.

Keywords: Crimea, geopolitics, geo-economics, entrepreneurship, business development.

Павлішина Ніна. Розвиток бізнесу криму в умовах геополітичної невизначенності.

У роботі розглянуто бізнес-середовище Криму з погляду глобальних економічних та географічних перетворень. Проведено аналіз економічних показників, відмічено фактори, щяо негативно впливають на економічне становище республіки. Окреслено напрямки нормалізаиії геоекономічної ситуації Криму, що знаходиться у прямій залежності від геополітичної ситуаиії на півострові, з метою підвищення ефективності використання власних ресурсів для забезпечення процвітання.

Ключові слова: Крим, геополітика, геоекономіка, підприємництво, розвиток бізнесу.

Relevance of research topic. The last decades have been marked by global transformations that are emerging as a new geopolitical configuration of the world. At the same time, the processes that take place in Ukraine not only correspond to global trends but also partly cause them. In particular, the most important event from the point of view of geopolitics is the annexation of Crimea, which represents the change of zones of economic influence, because of which Ukraine became at the same time the center of geo-economic confrontation of two trade zones, thus becoming the object 
of world geopolitical relations in the determined entity, with their priorities and the ability to make them a reality.

Formulation of the problem. The purpose of the research is to study the status and trends of business development in the Crimea, to identify geopolitical and geoeconomic factors that impede its effective functioning, to outline directions of stabilization of the business environment of the republic.

Analysis of recent researches and publications. Issues of geopolitical and geo-economic relations are under review of such scientists as S. Huntington, O.I. Chablis, A.A. Mitrofanov, A.V. Anichkin, Y.B. Oiler. In particular, the geopolitical position of Crimea was studied by I.N. Voronin, L.A. Ozhegova, V.P. Petrov, K.Yu. Sikach, A.V. Shvets and others. However, the influence of geo-economic factors on business development in the republic has not been thoroughly studied, which made the research relevant.

Presenting main material. The geographical location of Ukraine is very convenient from a geopolitical position, being at the intersection of interests of Europe and the countries of the East, it has a chance to become both an object and a subject on the «chessboard» of geopolitics. Referring to M.M. Mitrofanova and A.A. Anichkin (Mitrofanov, AA \& Anichkin, AA, 2015, p.17), who define geopolitics as a science that «reveals the dependence of foreign policy on factors that allow them to control certain aspects of geographic space», we can note that current Ukraine's position is determined by significant political and economic instability, unfavorable investment climate, riskiness of business processes, corruption, contradictory legal framework, and other factors.

However, modern scholars have noted the economization of politics, the growing role and importance of financial diplomacy in solving international problems and conflicts, and the balancing of the border between domestic and foreign policy. The country's position is increasingly dependent on geo-economic space factors. Thus, strategic decisions are made taking into account both the geopolitical and geoeconomic coordinate system. It is the subjects of geo-economy that define and shape geopolitics and geo-strategy.

The annexation of Crimea by Russia in 2014. The Peninsula is a strategically important territory of the Black Sea and a meeting point of geopolitical interests of both Ukraine and Russia, as well as Turkey, the European Union, and the United States. Having considerable potential, Crimea has never been an independent entity, always being in one of the states and being in the area of attention of others. Crimea, as a geopolitical system, can be represented as three blocks:

- functional - geographical and economic potential. From the geography standpoint, Crimea is of interest as a sea route, a means of control of the Black SeaAzov region, the Kerch Strait, a naval base (Sevastopol), an opportunity to organize communications through the construction of the bridge. From an economic point of view, tourism, agriculture, services, fishing, viticulture are worth considering. The 
attractiveness of the republic increases the availability of oil and gas fields. However, the economy of Crimea is not self-sufficient;

- institutional - information and legal environment;

- territorial - border stability, ethnic identity, natural resource uniqueness, orientation to tourism.

Today, Crimea is actually under the control of the Russian Federation, but it is legally part of Ukraine, which causes the existence of a territorial dispute between the states, to which other countries whose authorities hold various positions on the Crimean issue are involved.

The annexation of Crimea and its transfer to the control of the Russian Federation changed, among other things, the business environment in the republic and led to the emergence of factors hampering the socio-economic development of the peninsula. Including:

- legal uncertainty of territorial affiliation;

- the presence of sanctions by the leading powers of the world and Ukraine;

- risk of international cooperation;

- the weakening of foreign economic relations;

- poor infrastructure and resources;

- the threat of raiding.

One of the factors affecting the business environment in Crimea is sectoral restrictions (restriction of financing in the capital market due to the threat of destabilization of the situation in Ukraine) - a complete or partial ban on the supply of goods and technologies. They are listed on the EU Sanctions Map page and presented in Figure 1.

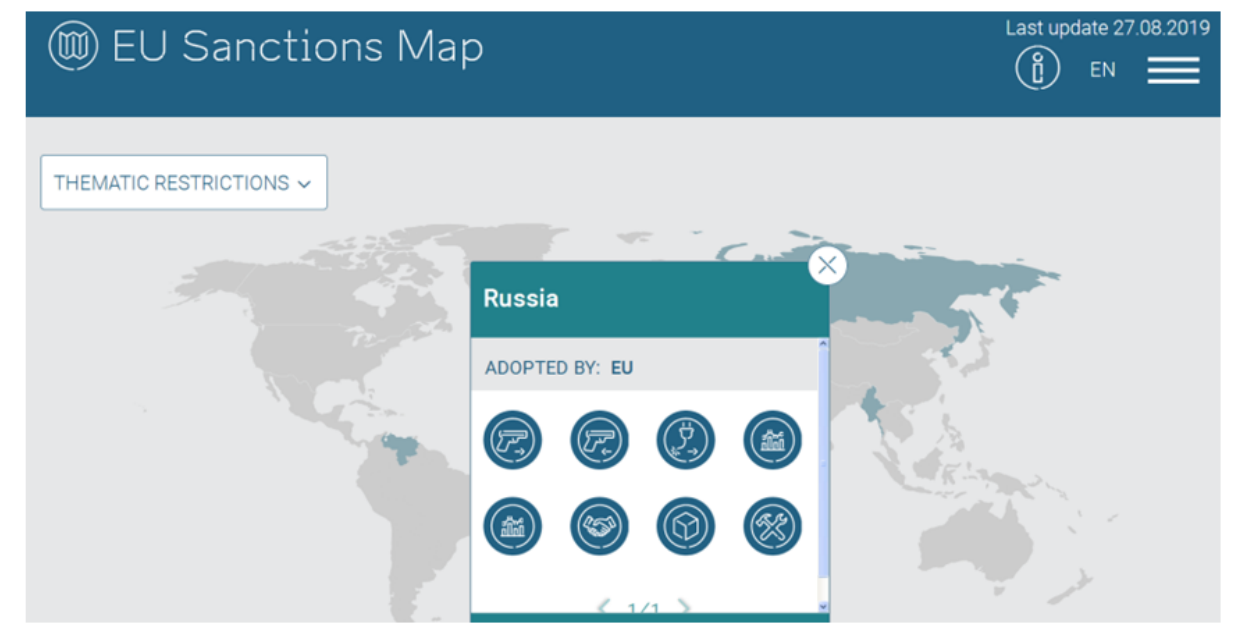

Figure 1. EU Sanctions Map

As you can see, a significant number of goods and services that are of strategic importance for the development of Crimea's business are subject to sanctions, in particular: export of certain equipment (for example, oil and gas, telecommunications, 
energy), dual-use goods and technologies, services ( training, service, construction, brokerage). There is a ban on the settlement of claims, on any transactions with certain financial instruments, etc. Imports of products made in Crimea are completely prohibited [EU Sanctions Map]. All major Crimean enterprises have come under sanctions. The banking system, including Visa and MasterCard (world payment systems) (temporarily) stop card servicing in Crimea, has also been affected.

The result of the imposition of sanctions was the total exit of foreign investors of Crimea.

Based on the statistics of the Crimea, one can get an idea of the state of business in the republic in the period 2014-2018.

The source of the data is research Goryunova, E (Goryunova, E.,2019, June 11), Kiviko, I.V. (Kiviko, I.V., 2018),, Department of the Federal State Statistics Service of the Republic of Crimea and Sevastopol (2019), Federal State Statistics Service (2019):

- Gross regional product (million rubles). 2018 data are adjusted according to GRP data for 2017 (Fig. 2);

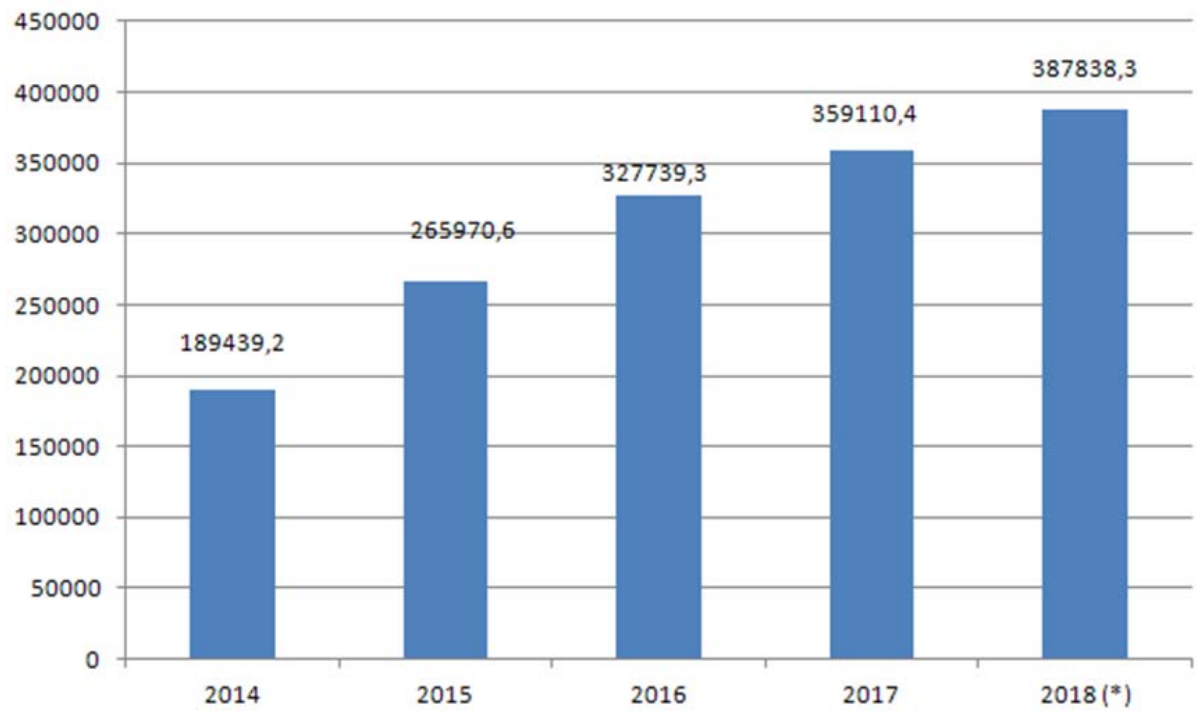

Figure 2. Crimea GRP

- investment development (state / own ratio,\%) (Fig. 3);

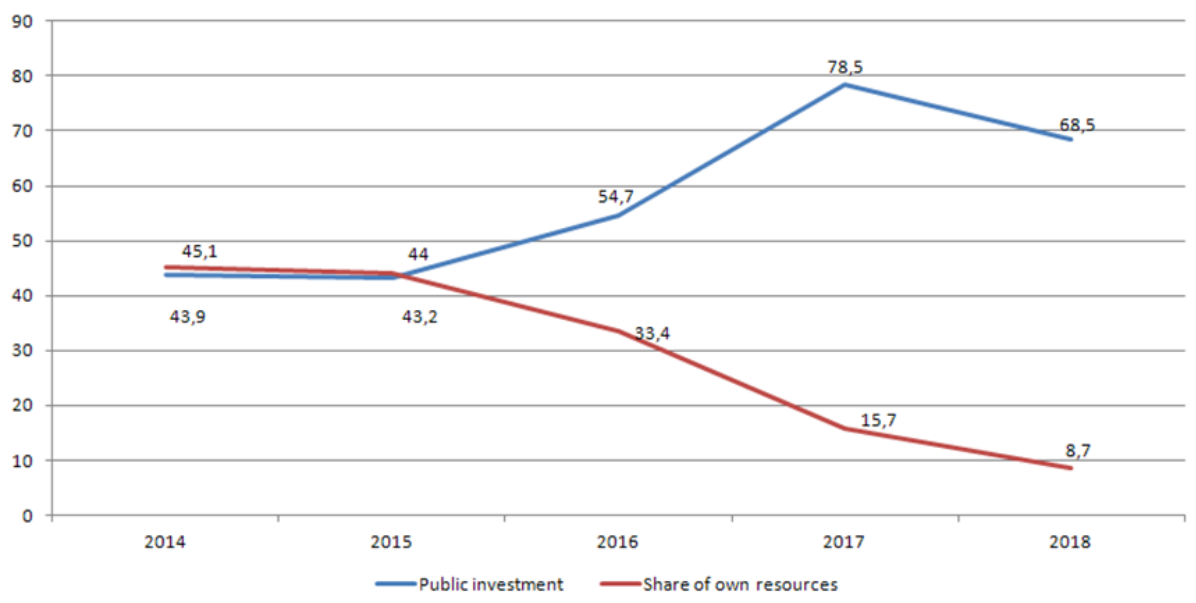

Figure 3. Investments in the Crimean economy by sources of funding 
- construction. The construction sector is one of the few to show growth. However, over 5 years, housing has grown by $19 \%$. However, it has not yet been possible to catch up with Ukrainian housing commissioning in the Crimea: 775,000 square meters of housing were commissioned in 2018 against 963,000 in 2013 (Goryunova, E., 2019, June 11);

- production of livestock products in the Crimea (in tons/millions of pieces for eggs) (Fig. 4). During the years of annexation of the cattle population on the peninsula decreased by $25-30 \%$, which led to a decrease in egg production by $12 \%$, meat - by $15 \%$, milk - by $17 \%$, and wool - by $20 \%$;

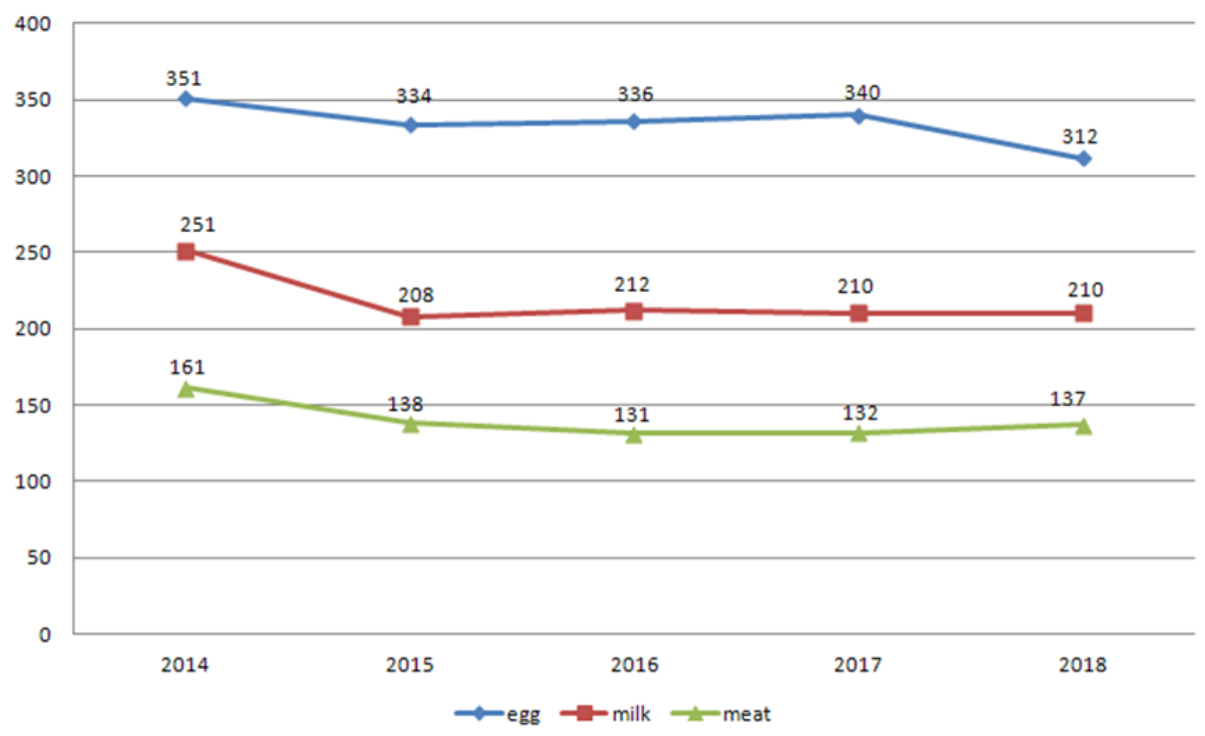

Figure 4. Production of livestock products

- turnover (Fig. 5). Freight traffic increased 5 times over 5 years. However, compared to 2013, it decreased to 3.4 times - from 1093 to 323 million tonne-kilometers.

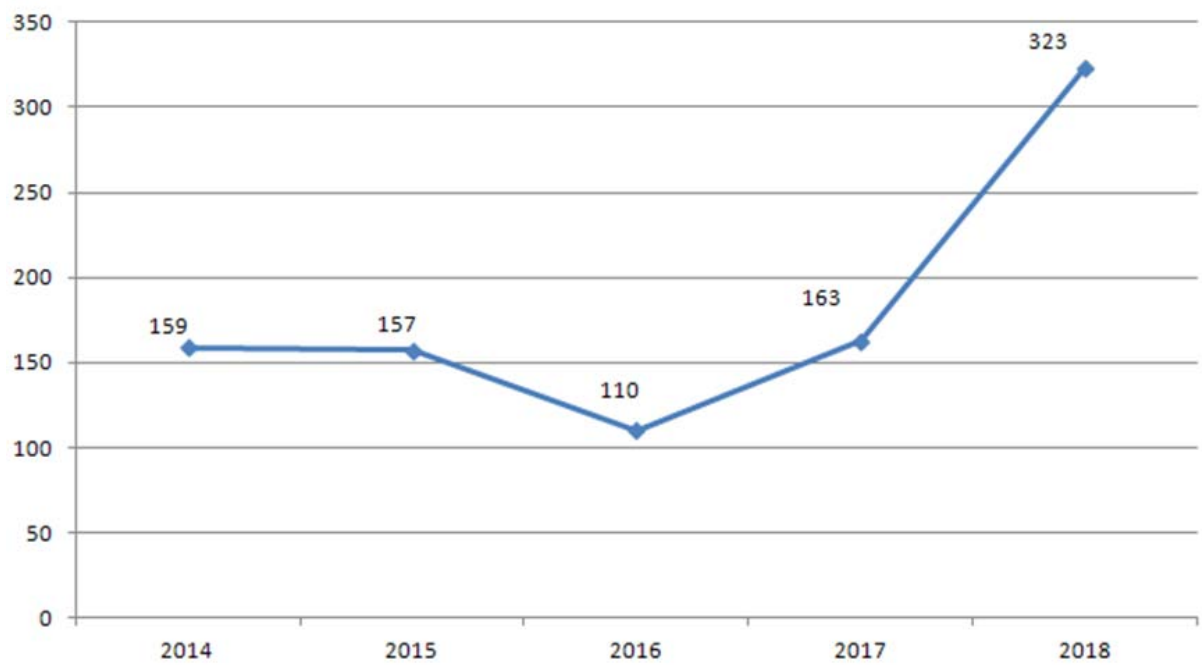

Figure 5. Freight traffic of trunks 
- trade (Fig. 6).

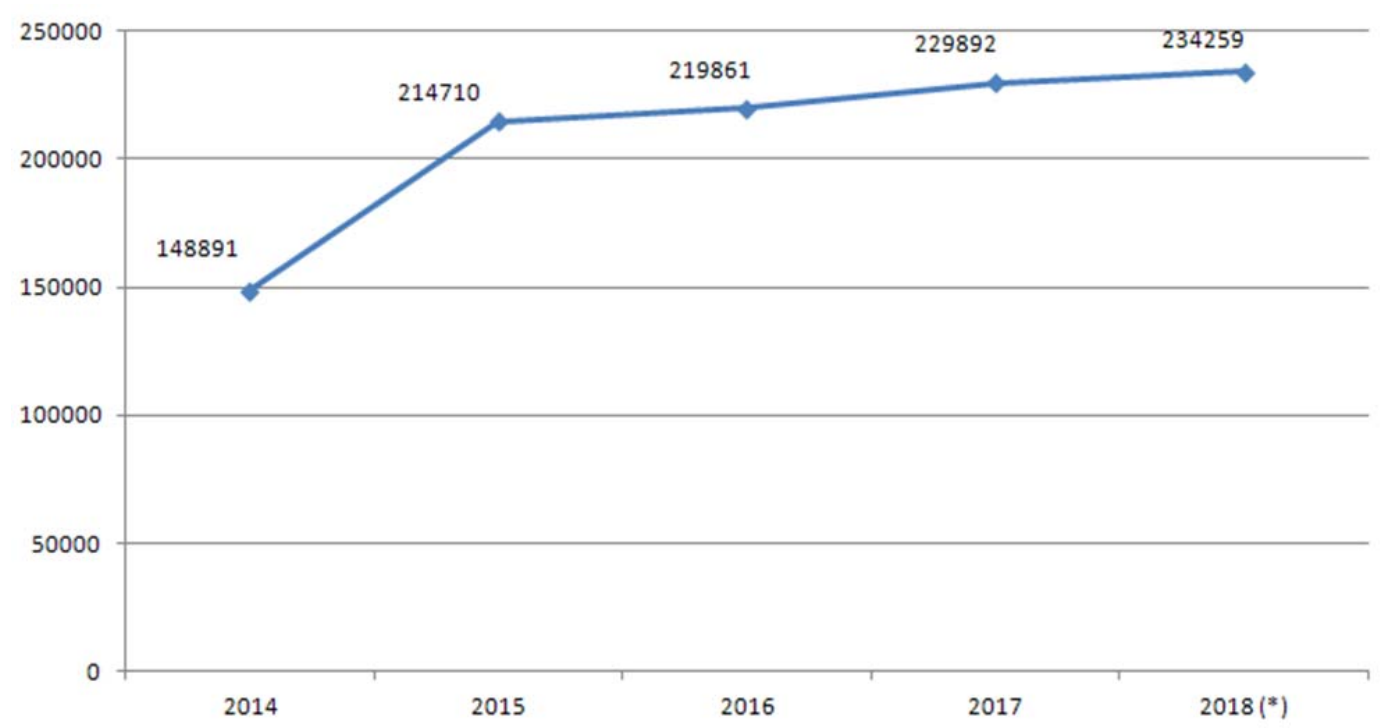

Figure 6. Retail trade in Crimea

Trade is the most profitable area of the economy. Trade turnover in the Crimea has increased by 2 times during the annexation period but decreased by $6 \%$ in dollar terms. Sales of bread and sugar (by 35\%), pasta (by 40\%), flour and tea (by 50\%) and salt - by $62 \%$, alcohol - 100\% increased significantly. Information for 2018 is adjusted according to the growth of the indicator for 2017;

- taxation (Fig. 7). Most sole proprietors prefer simplified taxation schemes. However, unlike the Ukrainian tax system, Russian provides for payment of taxes regardless of the result of entrepreneurial activity.

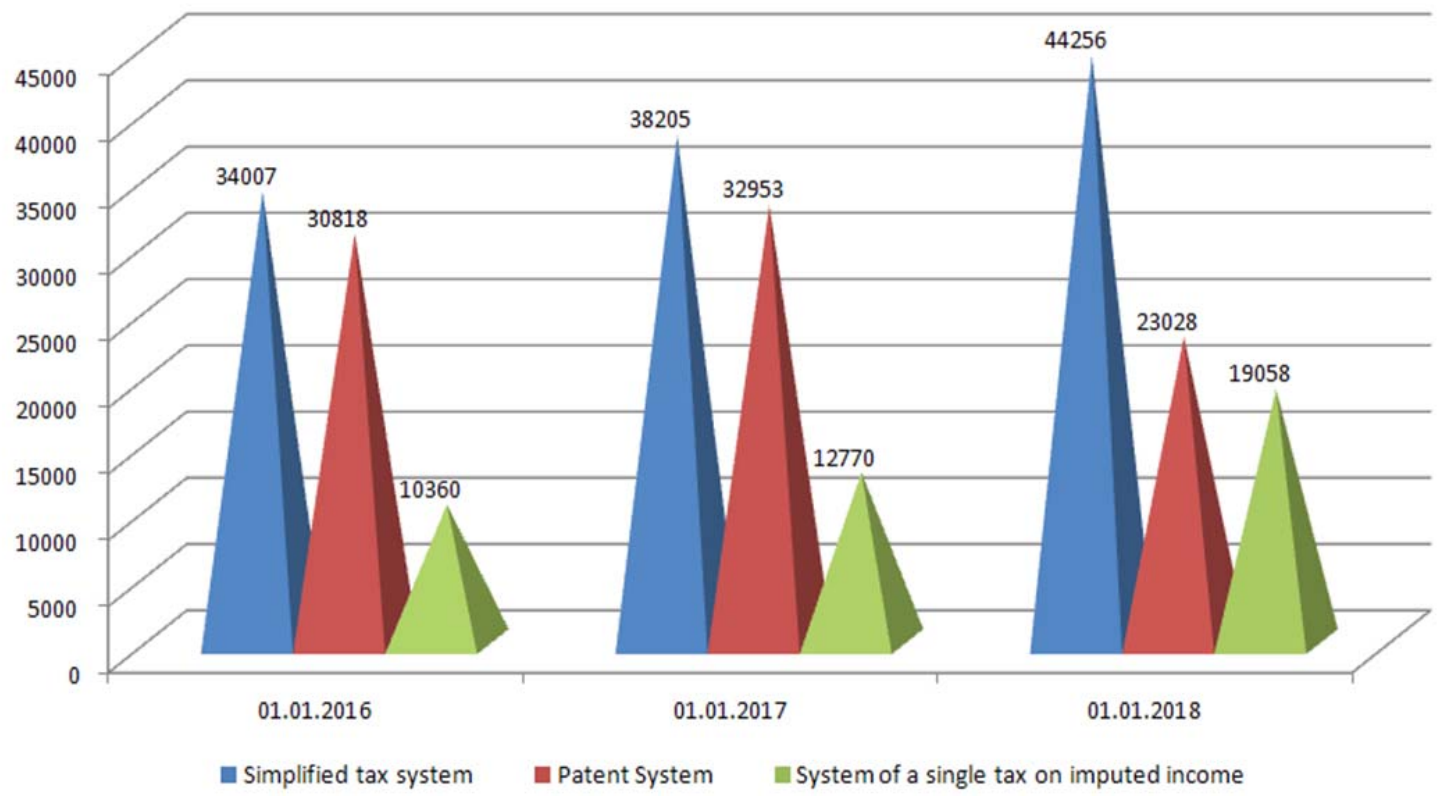

Figure 7. Special tax regimes selected by individual entrepreneurs 
If domestic trade shows growth (albeit mainly through inflation), foreign trade has virtually disappeared. Over the five years of occupation, Crimea's exports have fallen threefold - from $\$ 79.5$ to $\$ 23.8$ million, and imports have fallen from $\$ 100$ to $\$ 56$ million. Compared to Ukrainian times, foreign trade fell tenfold: exports 38 times, and imports - 18.6 times (Federal State Statistic Service (2019).

These data indicate a slow economic development. On this basis, the creation of small and medium-sized enterprises is a promising area for doing business in Crimea today. After all, big business is rather irreversible and unable to respond promptly to environmental changes. All over the world, business development requires government support. In the case of Crimea, the most important issue remains the issue of the territorial identity of the peninsula and its relation to the "Crimean issue» of the international community. Today's sanctions on Crimea are intended to become a destructive mechanism for Russia's economy.

However, the most essential prerequisites for the development of Crimea's business in the conditions of geopolitical and geo-economic instability can be determined:

- developing a business support program;

- simplification of tax pressure;

- providing access to markets;

- providing access to financial and information resources;

- favorable economic environment, deepening of cooperation with big business and the state;

- development of business infrastructure;

- reducing the level of «shadowing» of the economy;

- ensuring the «transparency» of the regulatory section.

Conclusion. Creating an opportunity for business development in the Crimea is a necessary prerequisite for the transition of the economy of the republic to increase the efficiency of business entities, employment problems, and is of particular importance in the uncertainty of the position of Crimea in the world arena and its territorial affiliation. However, to enhance geopolitical influence and geo-economic positions, Ukraine should strive for a speedy solution of the «Crimean issue» and not allow the predominance of a particular vector of geopolitical orientation. It is necessary to assert the sovereignty of Crimea, which is an continued of the territory of Ukraine and is of great importance for the country.

\section{REFERENCES}

1. EU Sanctions Map. (2019). Retrieved from https://sanctionsmap.eu/

2. Goryunova, E. (2019, June 11). Crimean economy: from «devastation to revival»? Retrieved from https://ru.krymr.com/a/ekonomika-krima-razruha-ilivozrojdenie/29991136.html 
3. Institutional Transformations in Economics. Office of the Federal State Statistics Service for the Republic of Crimea and the city of Sevastopol. Section «Entrepreneurship». (2019, March 5). Retrieved from https://gks.ru/folder/14036

4. Kiviko, I. V. (2018). Tax Regulation of Small Businesses in the Crimea. Economics, Taxes \& Law, 11(4), 125-132. doi: 10.26794/1999-849x-2018-11-4-125132

5. Krymstat-S. (2019). Republic of Crimea in numbers. 2018. Retrieved from https://crimea.gks.ru/wps/wcm/connect/rosstat_ts/crimea/resources /6f5a74804a17472c8ae3de3fbd401489/Крымвцифрах.2018(сайт).pdf

6. Mitrofanov, A. A., \& Anichkin, A. V. (2015). GEOPOLITICAL MODELS OF DEVELOPMENT OF THE RUSSIAN FEDERATION AFTER THE ACCESSION OF CRIMEA TO THE RUSSIAN FEDERATION. Ural Federal University Named after the First President of Russia B.N. Yeltsin Yekaterinburg, Russia. Retrieved from https://scienceforum.ru/2015/article/2015009031 